MANTHAN: Journal of Commerce and Management Volume 4, Issue 2, July-December 2017, pp. 1-12 doi: 10.17492/manthan.v4i02.11456

\title{
Causes and Effects of Occupational Stress in Private Sector: An Empirical Study for Kerala
}

Jayarajan T.K.* and R.Vasanthagopal**

\begin{abstract}
After decades of economic stagnation, the private sector has assumed critical significance as a generator of employment and as a contributor to the economy of a country. It is a known fact that employees working in the private sector are encompassing stress-related problems and many have imbibed coping techniques. The empirical study, based on a sample size of 450 executives in the three regions of Kerala spread across insurance, IT and banking sectors, aims to assess the causes of stress and its effects among executives in the private insurance, IT and banking sectors in Kerala (India). The study observed that though the causes of stress are different in these three sectors, work-related causes viz. working under pressure, monotonous and meaningless task, and long and unsocial hours are the major causes of stress among executives. The study also found a positive effect of stress on the psychological, physical and occupational levels of executives.
\end{abstract}

Keywords: Occupational effect; Occupational stress; Physical effect; Psychological effect; Kerala.

\subsection{Introduction}

In the modern world and concomitant life style, we say, people of all age groups are affected by stress and its dreaded consequences. Employee stress, the reaction of the employee to excessive pressures on account of external or internal factors, occurs whenever the body has to perform responsibilities that are beyond its range and scope and it results in harm and is damaging to employees, their organisations, families, and to society at large. In India there has been a noteworthy transformation in insurance, IT and banking sectors, particularly in the private sector in post-liberalization era.

*Assistant Professor, Payyanur College, Kannur, Kerala, India. (Email id: jayarajtk@gmail.com) **Corresponding author; Assistant Professor, School of Distance Education, University of Kerala,Trivandrum, Kerala, India. (Email id: vasanthagopalr@gmail.com) 
2 | MANTHAN: Journal of Commerce and Management, Volume 4, Issue 2, Jul-Dec 2017

This can mainly be attributed to the largest pool of professionally and technically qualified high class manpower. These sectors, in an endeavour to achieve their goal, try to tie together the manpower to the maximum. This causes mental and psychological problems owing to uncontrolled stress, the outcomes of which have been found to be costly to the organization. The position of the workforce in insurance, IT and banking sectors in Kerala is also no different. The literature review further reveals that over 50 per cent of the workforce in insurance, IT and banking segments are encompassing stress-related problems and many have imbibed coping techniques. But when it comes to the studies conducted particularly in Kerala, no systematic effort has been put in by individual researchers either to expose the causes of work stress or its effects, and hence this study. The study also aims to test the hypotheses that there is no difference in the causes of stress among executives in private sector in Kerala and that stress has a negative effect on psychological, physical and occupational levels of executives in private sector in Kerala.

\subsection{Review of Literature}

Over the last four decades, extensive research has been conducted on occupational stress, its causes and effects as it is the single biggest contributor to occupational diseases and work-related ailments. Henkoff (2009) found that the main cause of occupational stress is the organisation in which the individual is working. Job satisfaction is inversely proportional to level of stress. Floyd and Woolridge (2012) observed that the less the level of job satisfaction, the more the level of occupational stress. Muirhead (2013) points out that restriction on freedom of the individual, autonomy and identity are further causes of occupational stress. Whittington et al. (2012) point out that improper behaviour on the part of the management and poor supervisory styles are the main causes of occupational stress. Mayer et al. (2012) point out that role ambiguity and role conflict are two big causes of stress. Greenberg and Baron (2012) are of the view that increased levels of communication and interactions between supervisors and their workers minimise both role conflict and ambiguities resulting in lower levels of stress and stress-related disorders

Balogun et al. (2007) observed that decision control is an important contributor to work-related stresses. It represents the extent to which employees are allowed to participate in the decision making processes and the freedom given to employees to choose their work. Hildebrandt (2010) believes that more control on the job increases and improves the coping ability of employees during times of high job demand. Low job control on the other hand was found to lead to lowered levels of job performance. Lewin 
and Johnston (2010) point out that the real cause of occupational stress is not the work environment, but is more dependent on the persons involved in the workplace and hence the most effective way to reduce and even eliminate stress is to change the person-based factors. According to Teriyama et al. (2012) change at the workplace is one of the most common causes of occupational stress. Schilling and Steensma (2010) point out several causes of change in the workplace. These include changes due to technology, organizational restructuring and work redesign as well.

On reviewing the studies on the effects of stress, Noer (2011) found that excessive working hours result in work stress leading to more hypertension amongst employees. The study conducted in California found that individuals working forty hours a week were $20 \%$ more likely to report hyper tension than those who worked lesser number of hours; and those who worked between 41 to 50 hours every week were $25 \%$ more likely to report cases of hypertension. Palliam et al., (2014) points out the link between various psychiatric disorders and stress. A study conducted in Canada amongst working persons of different ages and occupations shows how work-related stress exacerbate psychiatric disorders which in turn leads to physical ailments. Working for long hours was found to result in musculo-skeletal problems and work injuries. Shah (2011) studied the impact of overtime and worker health in Japan. It was found that overtime is directly associated with cardiac problems, heightened blood pressure, more injury, weight gain and increased incidence of alcoholism.

The research conducted by Jones Lang Lasalle (2011) found higher levels of occupational stress amongst employees of private sector banks as compared to employees of nationalized banks. Band and Tustin (2011) conducted a cross-section study amongst 200 IT professionals in the National Capital Region (NCR) of Delhi. The study found that of the 200 respondents, computer-related morbidity existed in $93 \%$ of them at different levels. $76 \%$ of them suffered from visual problems, $77.5 \%$ from musculo-skeletal disorders, while 35\% of them suffered from symptoms of stress. Fontana (1996) studied the impact of stress amongst women employees of call centers in Indore and the particular problems faced by them. The study found that work-lifebalance severely impacted stress levels amongst female call centre employees. The monotony of call centre jobs, coupled with abuse from clients, result in higher levels of stress causing them to over-react to various situations. Nanda (2006) identified six factors that contribute to stress levels amongst IT professionals in India. These include demands of the job, control over work, colleague, managerial support, work levels, job clarity and organizational change.

Marimuthu (2009) found that too many tasks, work overload, conflicting demands both from colleagues and superiors, incompatibility of demands on the personal 
4 | MANTHAN: Journal of Commerce and Management, Volume 4, Issue 2, Jul-Dec 2017

and professional fronts, the inadequate provisioning of resources for performance, inadequate competency levels, a lack of autonomy to make decisions and a feeling of under-utilization, all contributed to higher levels of stress amongst the employees IT companies. Proctor (2010) found that the issues related to security of job as well as those related to remuneration, emoluments and benefits were the staple causes of stress in the insurance sector. The study conducted by Band and Tustin (2011) indicated that nearly a third of the working population in the insurance sector of developed countries of the West, consistently report high to very high levels of stress. Similar symptoms have been reported amongst employees of the insurance sector in emerging economies such as India and China. The particular factors that operate as contributors of stress in the insurance sector include time, excessive work demands, conflict of roles, ergonomic deficiencies, job insecurities and bad relationships with clients and customers. NorthWestern National Life Insurance (2013) studied stress level ratios in their offices and found a significant and positive correlation between the phenomenon of absenteeism and work-related stress. In their study $27 \%$ of the respondents said that their jobs contributed to stress in their lives; of them $46 \%$ indicating very to extremely high levels of job stress levels.

Mansor et al., (2013) studied the sources of occupational stress amongst Malaysian employees in an insurance firm in Kuala Lumpur. They found that the extent of work load, working conditions and work relationships were the main issues impacting stress levels amongst managers in the Malaysian insurance sector. Yammarino and Dubinsky (1987) conducted a study of stress amongst employees of the Japanese insurance industry. They found that stress levels are dependent on the employee commitment to their organizations and the level of satisfaction with their supervisors.

The foregoing analysis of the review of studies on occupational stress reveals that occupational stress has become a common phenomenon amongst workers across the world. The quantity of work is found to be an important source of stress where shorter working hours result in lowered amounts of stress while longer working hours produce more stress. Low job control is another major source of stress. Low support from surrounding superiors and colleagues strained relationships at work; role ambiguities, conflict of role, workplace harassment, bullying, being unable to adjust to changes in the working system etc. result in heightened levels of stress. On reviewing the studies on banking, IT and insurance sectors it is found that cutting across age levels work stress impacts everybody to a varying extent. Women are found to be more susceptible to occupational stress as compared to men. Again, stress is more amongst those who work in the private sector as compared to those who work in the public sector. Further, occupational stress is present in both white and blue-collar workers. Meanwhile, 
occupational stress as a phenomenon is most commonly studied in Western countries while it has been ignored in developing countries like India. Also, there hasn't been any significant attempt in the state of Kerala to study the causes and effects of stress in the public sector or the emerging private sector.

\subsection{Methodology}

The study is empirical in nature based on observed and field data collected from the sample executives by administering a structured interview schedule. The executives working in information technology (IT), banking and insurance sectors in Kerala constitute the universe of the study. Fifty (50) executives each from the South, Central and North regions of Kerala spread across insurance, IT and banking sectors were taken as samples that constitute a total of 450 executives. For data analysis, statistical tools such as average, percentage, Pearson correlation, mean score, ANOVA and post hoc test were used.

\subsection{Results and Discussion}

\subsection{Causes of stress}

Stress can be caused by a physical or emotional change, or a change in one's environment that requires him/her to adjust or respond. The causes of stress selected for the analysis include: (i) organisational related causes, (ii) interpersonal relation related causes, (iii) work related causes, (iv) financial related causes, and (v) family related causes. On examining organisational related causes of stress in detail, all the employees irrespective of the sectors gave top priority to job insecurity as supreme factor. While isolated and solitary work is cited as the main reason for interpersonal relation related causes of stress by the employees in the insurance sector bullying, harassment and violence are the important factors by the employees in the banking sector. In case of employees in the insurance sector, absence of rigid procedure for dealing with problems or complaints are attributed as the most preferred reason. With regard to work related causes, employees in insurance and IT sectors viewed working under pressure as the ultimate reason for stress whereas employees in the banking sector found monotonous and meaningless task as the grave reasons for such stress. On analysing the stress caused by finance related matters, the employees in all the sectors unanimously pointed out that loan repayment is the most important factor. On examining stress caused by family related matters, inadequacy of time to spend with the family has cited as the prime factor by the employees in the insurance and banking sectors. However, in IT, the employees 
ranked health problems of the family as the most important factor. The rankings of various causes of stress for the three sectors are given in Table 1. The opinion of executives as the causes of stress has also been put to hypothesis testing to find whether there find any difference in the causes of stress among them.

\section{Table 1: Causes of Stress (Overall View)}

\begin{tabular}{|l|c|c|c|c|c|c|}
\hline \multirow{2}{*}{\multicolumn{1}{|c|}{ Cause of Stress }} & \multicolumn{2}{|c|}{ Insurance } & \multicolumn{2}{c|}{ I T } & \multicolumn{2}{c|}{ Banking } \\
\cline { 2 - 7 } & Mean & Rank & Mean & Rank & Mean & Rank \\
\hline Organisational related & 3.5600 & 4 & 3.7600 & 3 & 3.9800 & 2 \\
\hline $\begin{array}{l}\text { Interpersonal relations } \\
\text { related }\end{array}$ & 3.6000 & 3 & 3.5600 & 4 & 3.3867 & 5 \\
\hline Work related & 4.3867 & 1 & 4.4467 & 1 & 4.8200 & 1 \\
\hline Financial related & 3.9067 & 2 & 3.9933 & 2 & 3.9133 & 3 \\
\hline Family related & 3.4800 & 5 & 3.2800 & 5 & 3.4667 & 4 \\
\hline Others & 0.7467 & 6 & 1.2200 & 6 & 0.8400 & 6 \\
\hline
\end{tabular}

Source: Primary data.

As per the mean score, work related causes are major causes of stress among executives in the three sectors (Table 1). However, there is variation among executives in all the three sectors as to the other causes of stress. A comparison has also been made by using ANOVA to test whether there is any difference between groups or within groups as to the causes of stress among executives. The analysis reveals a significant difference of opinion among the executives with regard to all the causes of stress except financial related causes (Table 2). Further, multiple comparison with post hoc test has also been made. The test finds that the mean difference in the causes of stress among executives in the private insurance, IT and banking sectors is significant at 5\% level (Table 3). Hence the null hypothesis stating that there is no difference in the causes of stress among executives in the private sector in Kerala stands rejected.

\subsection{Effects of stress}

The life of employees today, particularly that of employees in the private sector, is awfully stressful, which in turn imposes high physical demands on their body and emotional costs on their lives. While reviewing studies conducted in India and abroad it is observed that stressful working conditions result in several problems in workforce such as low productivity, increased absenteeism, excessive staff turnover, alcoholism, hypertension, cardiovascular problems and so on and so forth. In the study an analysis 
has also been made to assess the effect of stress on employees in the private insurance, IT and banking sectors in Kerala. Generally, stress may create psychological, physical and occupational effects on employees and hence the three effects have been the subject matter of the analysis.

For measuring the psychological effect of stress, variables viz. anxiety, boredom, low self-esteem, forgetfulness, depression, anger, apathy/worry, insomnia etc. have been used. On analysing the combined psychological effect of stress (based on mean), anxiety is ranked first as a major effect of stress among executives. For measuring the physical impact of stress, variables viz. head ache, diabetes, hypertension, chest and back pain, ulcers, hair loss and upset stomach have been used. On analysing the combined physical effect of stress, head ache has ranked first as a major result among the physical effects considered.For measuring the occupational impact of stress, variables viz. getting totally exhausted at the end of the day at work place, feeling irritated, nervous and angry, total dissatisfaction with the job while performing it, thinking of job-quitting, feeling calm and relaxed at work, taking a number of days of leave, family life related problems, doing work in the best way and (i) weak health conditions. On analysing the combined occupational effect of stress, totally exhausted at the end of the day at work place is a major occupational problem which is created by stress.

Table 2: Causes of Stress (ANOVA)

\begin{tabular}{|c|c|c|c|c|c|c|}
\hline Causes & Comparison & $\begin{array}{c}\text { Sum of } \\
\text { Squares }\end{array}$ & Df & $\begin{array}{c}\text { Mean } \\
\text { Square }\end{array}$ & $\mathbf{F}$ & Sig. \\
\hline \multirow{3}{*}{$\begin{array}{l}\text { Organizational } \\
\text { related }\end{array}$} & Between Groups & 22.085 & 2 & 11.042 & 6.867 & .001 \\
\hline & Within Groups & 693.042 & 431 & 1.608 & & \\
\hline & Total & 715.127 & 433 & & & \\
\hline \multirow{3}{*}{$\begin{array}{l}\text { Interpersonal } \\
\text { related }\end{array}$} & Between Groups & 8.779 & 2 & 4.389 & 3.019 & .050 \\
\hline & Within Groups & 625.258 & 430 & 1.454 & & \\
\hline & Total & 634.037 & 432 & & & \\
\hline \multirow{3}{*}{ Work related } & Between Groups & 32.661 & 2 & 16.330 & 9.557 & .000 \\
\hline & Within Groups & 748.446 & 438 & 1.709 & & \\
\hline & Total & 781.107 & 440 & & & \\
\hline \multirow{3}{*}{$\begin{array}{l}\text { Financial } \\
\text { related }\end{array}$} & Between Groups & 9.238 & 2 & 4.619 & 2.343 & .097 \\
\hline & Within Groups & 849.776 & 431 & 1.972 & & \\
\hline & Total & 859.014 & 433 & & & \\
\hline \multirow{3}{*}{ Family related } & Between Groups & 9.238 & 2 & 4.619 & 2.343 & .097 \\
\hline & Within Groups & 849.776 & 431 & 1.972 & & \\
\hline & Total & 859.014 & 433 & & & \\
\hline
\end{tabular}


8 | MANTHAN: Journal of Commerce and Management, Volume 4, Issue 2, Jul-Dec 2017

Table 3: Cause of Stress - Multiple Comparison using Post Hoc Tests

\begin{tabular}{|c|c|c|c|c|c|c|c|}
\hline \multirow{2}{*}{ Variable } & \multirow{2}{*}{\multicolumn{2}{|c|}{ Sectors }} & \multirow{2}{*}{$\begin{array}{c}\text { Mean } \\
\text { Differen } \\
\text { ce }(\mathbf{I}-\mathbf{J})\end{array}$} & \multirow{2}{*}{$\begin{array}{l}\text { Std. } \\
\text { Error }\end{array}$} & \multirow{2}{*}{ Sig. } & \multicolumn{2}{|c|}{$\begin{array}{l}\text { 95\% Confidence } \\
\text { Interval }\end{array}$} \\
\hline & & & & & & $\begin{array}{l}\text { Lower } \\
\text { Bound }\end{array}$ & $\begin{array}{l}\text { Upper } \\
\text { Bound }\end{array}$ \\
\hline \multirow{6}{*}{$\begin{array}{l}\text { Organization } \\
\text { al related } \\
\text { cause of } \\
\text { stress }\end{array}$} & \multirow[b]{2}{*}{ Insurance } & IT & .26141 & .14898 & .080 & -.0314 & .5542 \\
\hline & & Banking & $-.29488^{*}$ & .14818 & .047 & -.5861 & -.0036 \\
\hline & \multirow{2}{*}{ IT } & Insurance & -.26141 & .14898 & .080 & -.5542 & .0314 \\
\hline & & Banking & $-.55629^{*}$ & .15024 & .000 & -.8516 & -.2610 \\
\hline & \multirow{2}{*}{ Banking } & Insurance & $.29488^{*}$ & .14818 & .047 & .0036 & .5861 \\
\hline & & IT & $.55629^{*}$ & .15024 & .000 & .2610 & .8516 \\
\hline \multirow{6}{*}{$\begin{array}{l}\text { Interpersonal } \\
\text { related } \\
\text { causes of } \\
\text { stress }\end{array}$} & \multirow{2}{*}{ Insurance } & IT & -.22602 & .14189 & .112 & -.5049 & .0529 \\
\hline & & Banking & .11905 & .14138 & .400 & -.1588 & .3969 \\
\hline & \multirow{2}{*}{ IT } & Insurance & .22602 & .14189 & .112 & -.0529 & .5049 \\
\hline & & Banking & $.34507^{*}$ & .14261 & .016 & .0648 & .6254 \\
\hline & \multirow{2}{*}{ Banking } & Insurance & -.11905 & .14138 & .400 & -.3969 & .1588 \\
\hline & & IT & $-.34507^{*}$ & .14261 & .016 & -.6254 & -.0648 \\
\hline \multirow{6}{*}{$\begin{array}{l}\text { Work related } \\
\text { causes of } \\
\text { stress }\end{array}$} & \multirow{2}{*}{ Insurance } & IT & $.57704^{*}$ & .15249 & .000 & .2773 & .8767 \\
\hline & & Banking & -.00452 & .15196 & .976 & -.3032 & .2941 \\
\hline & \multirow{2}{*}{ IT } & Insurance & $-.57704^{*}$ & .15249 & .000 & -.8767 & -.2773 \\
\hline & & Banking & $-.58156^{*}$ & .15300 & .000 & -.8823 & -.2809 \\
\hline & \multirow{2}{*}{ Banking } & Insurance & .00452 & .15196 & .976 & -.2941 & .3032 \\
\hline & & IT & $.58156^{*}$ & .15300 & .000 & .2809 & .8823 \\
\hline \multirow{6}{*}{$\begin{array}{l}\text { Financial } \\
\text { related } \\
\text { causes of } \\
\text { stress }\end{array}$} & \multirow{2}{*}{ Insurance } & IT & -.19518 & .16524 & .238 & -.5200 & .1296 \\
\hline & & Banking & .16398 & .16407 & .318 & -.1585 & .4865 \\
\hline & \multirow{2}{*}{ IT } & Insurance & .19518 & .16524 & .238 & -.1296 & .5200 \\
\hline & & Banking & $.35916^{*}$ & .16607 & .031 & .0327 & .6856 \\
\hline & \multirow{2}{*}{ Banking } & Insurance & -.16398 & .16407 & .318 & -.4865 & .1585 \\
\hline & & IT & $-.35916^{*}$ & .16607 & .031 & -.6856 & -.0327 \\
\hline \multirow{6}{*}{$\begin{array}{l}\text { Family } \\
\text { related } \\
\text { causes of } \\
\text { stress }\end{array}$} & \multirow{2}{*}{ Insurance } & IT & $-.78862^{*}$ & .17751 & .000 & \#\#\#\#\# & -.4397 \\
\hline & & Banking & .25904 & .17782 & .146 & -.0905 & .6085 \\
\hline & \multirow{2}{*}{ IT } & Insurance & $.78862^{*}$ & .17751 & .000 & .4397 & 1.138 \\
\hline & & Banking & $1.04765^{*}$ & .17812 & .000 & .6976 & 1.397 \\
\hline & \multirow[b]{2}{*}{ Banking } & Insurance & -.25904 & .17782 & .146 & -.6085 & .0905 \\
\hline & & IT & $\begin{array}{c}- \\
1.04765^{*}\end{array}$ & .17812 & .000 & \#\#\#\#\# & -.6976 \\
\hline
\end{tabular}

Note: *The mean difference is significant at $5 \%$ level.

In the study an analysis has also been made to test the hypothesis that stress has a negative effect on psychological, physical and occupational levels of executives in the 
private insurance, IT and banking sectors in Kerala. As per ANOVA test, based on mean value, it is observed that anxiety is the major psychological effect of stress (Mean =3.4). While head ache is the major physical effect of stress (Mean=3.4), totally exhausted at the end of the day at work place is the major occupational effect of stress (Mean=3.2). Again, to know the effect of stress on psychological, physical and occupational level of executives' Persons correlation has been applied. The correlation finds a significant relationship between stress and psychological, physical and occupational levels of executives (Table 4). Hence the null hypothesis stating that stress has a negative effect on psychological, physical and occupational levels of executives in the private insurance, IT and banking sectors in Kerala stands rejected.

Table 4: Effects of Stress among Executives

\begin{tabular}{|c|c|c|c|c|c|}
\hline $\begin{array}{c}\text { Causes of } \\
\text { stress }\end{array}$ & & $\begin{array}{c}\text { Psychological } \\
\text { Effects }\end{array}$ & $\begin{array}{l}\text { Physical } \\
\text { Effects }\end{array}$ & $\begin{array}{c}\text { Occupational } \\
\text { Effects }\end{array}$ & Total \\
\hline \multirow{3}{*}{$\begin{array}{l}\text { Organizational } \\
\text { related }\end{array}$} & Correlation & .142 & .170 & .187 & $.181 *$ \\
\hline & Sig. (2-tailed) & .083 & .038 & .022 & .046 \\
\hline & $\mathrm{N}$ & 450 & 450 & 450 & 450 \\
\hline \multirow{3}{*}{$\begin{array}{l}\text { Interpersonal } \\
\text { related }\end{array}$} & Correlation & .124 & .138 & .145 & $.167 *$ \\
\hline & Sig. (2-tailed) & .072 & .039 & .042 & .042 \\
\hline & $\mathrm{N}$ & 450 & 450 & 450 & 450 \\
\hline \multirow{3}{*}{ Work related } & Correlation & .177 & .138 & .191 & $.194 *$ \\
\hline & Sig. (2-tailed) & .050 & .093 & .013 & .015 \\
\hline & $\mathrm{N}$ & 450 & 450 & 450 & 450 \\
\hline \multirow{3}{*}{$\begin{array}{l}\text { Financial } \\
\text { related }\end{array}$} & Correlation & .195 & .139 & .129 & $.152 *$ \\
\hline & Sig. (2-tailed) & .047 & .091 & .011 & .046 \\
\hline & $\mathrm{N}$ & 450 & 450 & 450 & 450 \\
\hline \multirow[t]{3}{*}{ Family related } & Correlation & .120 & .142 & .126 & $.124 *$ \\
\hline & Sig. (2-tailed) & .044 & .048 & .038 & .044 \\
\hline & $\mathrm{N}$ & 450 & 450 & 450 & 450 \\
\hline
\end{tabular}

Note: *Correlation is significant at 5\% level (2-tailed).

\subsection{Conclusion}

In conformity with the general understanding that stress is a common and contagious feature of modern life, the executives in private sector in Kerala are also more prone to stress today. The detailed analysis of the study arrived at the following conclusions: 
(i) Organisational, interpersonal, work, financial and family related causes are the main causes of stress among executives in private sector in Kerala. Among the five causes, work-related causes are very significant. Finance-related and organisation-related causes are the other major causes of stress.

(ii) Though the study found significant difference of opinion among executives on the causes of stress, apprehension on job security, isolated and solitary work, working under pressure, fear of loan default, and inadequacy of time to spend with the family are the main concerns under the organisational, interpersonal, work, financial and family related causes of stress respectively.

(iii) The study found that stress creates psychological, physical and occupational effects on executives in private sector. Anxiety, headache, and getting totally exhausted at the end of the day at work place are the psychological, physical and occupational effects of stress respectively.

(iv) We also found a significant relationship between stress and psychological, physical and occupational levels of executives in private sector.

\section{References}

Balogun, J., Jarzabkowski, P., \& Seidl, D. (2007). Strategizing activity and practice. In V. Ambrosini \& M. Jenkins (eds.) Advanced Strategic Management (Chapter 12, pp. 196-214). Basingstoke, UK: Palgrave.

Band, D., \& Tustin, C. (2011). Strategic downsizing. Management Decision, 33(8), 3645 .

Floyd, S.W. \& Wooldridge, B. (2012). Middle management's strategic influence and organizational performance. Journal of Management Studies. 34(3), 465-485.

Fontana, D. (1996). Managing Stress. New Delhi: Excel Publishers.

Greenberg, J., \& Baron, A. R. (2012). Behaviour in organizations: Understanding and managing the human side of work. New Jersey: Prentice Hall, Inc.

Henkoff, R. (2009). Cost cutting: How to do it right. Fortune. 119, 40-49.

Hildebrandt, A. (2010). Empirical evidence on shareholder value effects of corporate restructuring. Verlag: GRIN . 
Jones Lang Lasalle (2011). Trends in the Banking and Finance Sector: Global Corporate Real Estate Survey.

Lewin, J. E \& Johnston, W. J. (2010). The impact of downsizing and restructuring on organizational competitiveness. Competiveness Review. 10(1), 45-55.

Mansor, N. A., Che-Ahmad, A., Ahmad Zaluki, N. A. \& Osman, A.H. (2013). Corporate governance and earnings management: A study on the Malaysian family and non-family owned PLCs. Procedia Economics and Finance, 7, 221-229.

Marimuthu, M. (2009). Corporate restructuring, firm characteristics and implications of capital structure: An academic view. International Journal of Business Management. 4(1), 123.

Mayer, M., Smith, A. \& Whittington, R. (2012). Organising for success in the 21 st century, CEOs' and HR managers' perceptions. London: Chartered Institute of Personnel and Development.

Muirhead, S. (2013). Crisis Banking in the East: The History of the Chartered Mercantile Bank of India, London and China, 1853-93. Aldershot: Scolar Press.

Nanda, M. (2006). Dynamic Life Management: Stress-free Living. New Delhi: India Log Publishers.

Noer, D.M. (2011). Healing the Wounds: Overcoming the Trauma of Layoffs and Revitalizing Downsized Organizations. San Francisco: Jossey-bass Publishers, Inc.

Palliam, R. \& Shalhoub, K. Z. (2014). Rationalizing corporate downsizing with longterm profitability - an empirical focus. Management Decision. 40(5), 436 - 447.

Proctor, T. (2010). Corporate restructuring: The pitfalls of changing industry structure. Management Decision, 39(3), 197- 204.

Schilling, M.A \& Steensma, H.K (2010). The use of modular organizational forms: An industry-level analysis. Academy of Management, 44(6), 1149-1168. 
12 | MANTHAN: Journal of Commerce and Management, Volume 4, Issue 2, Jul-Dec 2017

Shah, P. P. (2011). Network destruction: The structural implications of downsizing. Academy of Management Journal, 43(1), 101-112.

Teriyama, S. J., Agburu, J. I. \& Timothy, A. (2012). The management of downsizing in business organization: A survey of Skye Bank Plc. in Benue State and Nasarawa State. Global Advanced Research Journal of Management and Business Studies, 1(4), 103-114.

Whittington, R., Molloy, E., Mayer, M., \& Smith, A. (2012). Practices of strategising/organising: Broadening strategy work and skills. Long Range Planning, 39(6), 615-29.

Yammarino, F.J., \& Dubinsky, A.J. (1987). On job satisfaction: It's the relationships that count! Journal of Risk and Insurance, 54, 804-809. 